\title{
Global Economic Melt -Down and the Nigerian Banking Industry-A Review
}

\author{
Ayodele Thomas D., Oke Margaret A. \\ ${ }^{1}$ Dept. of accounting and finance, Ajayi crowther university, Oyo. Nigeria. \\ ${ }^{2}$ Dept. of Economics, Ajayi crowther university, Oyo. Nigeria.
}

\begin{abstract}
The paper reviewed the impact of the recent global financial crisis on the Nigerian banking industry. The global financial crisis which originated from the united state of American has spread to other point of the world including Nigeria. This has caused the risk of global recession to be heightened significantly and the volatility of commodity prices, which is the main stay of most developing countries like Nigeria has increased further.

It was discover that, there has been a decline in export of Nigeria, cash drain from the economy, increase in unemployment, fall in equity market and decline in remittance from abroad among others. And up till the present moment, Nigerian banking industry is yet to recover fully from the financial shock even when other economies have recovered.

However, it was found out that problem comforting the Nigeria banking industry was not only the global phenomenon but large scale corruption which had made the banking sector unstable before the era of the global crisis.

It was recommended therefore that the monetary authority should be more fortified by the government of Nigeria, so that they can perform maximally and restore confidence and trust in the Nigerian financial system. The enabling environment should be created in other to attract more and serious minded investors to the economy in other to be able to maintain a buffer against any future financial shock.
\end{abstract}

Keywords: Adjustable rate mortgages, Banking sector, Financial crises, Housing bubbles, Monetary authorities

\section{Introduction}

As a result of the sudden bust of the United States housing bubble and high default rates of sub-prime and adjustable rate mortgages [ARMs]; home owners were unable to make their mortgage payment. Poor judgment by borrowers and lenders, speculation and overbuilding during the boom period further worsened the situation. Thus the development created adverse consequences for banks and financial market not just in the United States alone but also in other economies of the world. This resulted in declines in the capital of many banks coupled with tightening credit around the world.

Consequently, this evolved into a full -fledged financial crisis impacting the investment and commercial banking sectors and the insurance industry, with international transmission of the crisis to Europe and Japan and, eventually, to mainly the larger and more advanced developing countries.

The financial crisis then took on the peculiar characteristics of a credit crisis with the banks not wanting to lend [even after receiving bail-out resources] because of lack of confidence in the system. This led to a real sector economic crisis. In Nigeria, the decline in real sector production activities and growing unemployment then worsened the crisis for the financial sector of the economy.

It is generally accepted that the development of the banking sector is crucial to the survival of the entire economy. Therefore, efforts have been geared towards sustaining the sector by the various successive Nigerian governments. According to Nwankwo (1980), the financial system ought to perform particular functions. The banking sector intermediates between those who have surplus funds to lend and those who require borrowed funds. The efficient performance of fund mobilization and lending functions is lacking in most developing nations. This in most cases has been the foundation of crisis in the banking system.

Therefore, the crises in the emerging market economics that started in the financial sector have impacted the real sector. This has invariably resulted to some unfavourable economic development indicator resulting in a loss of confidence and a sudden withdrawal of sudden withdrawal of foreign portfolio capital, in the context of failure to impose capital control on the country's economic base.

The paper is therefore out to achieve the following objectives among others.

To determine the causes of bank failure globally and enumerate the basic principles and practices that can help the Nigerian banking sector in particular.

To examine the importance of the banking sector to the Nigerian economy at large. 
To undertake a broad review of survival strategies in the Nigerian banking sector for necessary insight into the operation of the global economic meltdown.

\section{The Causes Of Global Economic Melt Down}

Prior to the beginning of the crisis, there was ease in monetary policy designed to avoid recession, especially in United States of America. The inflow of funds combined with the low U.S. interest rates contributed significantly to easing credit conditions, which in turn triggered both housing and credit bubbles in the U.S. (Baker, 2008). It was a policy designed to encourage widespread home ownership in the U.S but turned out to become a sub- prime lending.

The foreclosing and declining property values left mortgage banks with huge non-performing assets (toxic assets), which in turn reduced the net worth of home owners and consequently impaired the spending ability of consumers on goods and services. Subprime lending eventually weakened some American banking institutions such that they had to approach the U.S government for loans to recapitalize in order to avoid bankruptcy. Due to the cheap borrowing by individuals with poor credit rating, the unprecedented lull in housing business in the U.S. Housing market led to the sudden burst of the U.S. housing bubble -and high default rate on sub-prime and Adjustment rate mortgages [ARMs]. As ARMs began to reset higher rates, mortgage payment delinquency rates began to rise rapidly. As noted by Soludo [2009], the development created adverse consequences for banks and financial markets not just in the U.S. alone but also in other economies like that of Nigeria.

Securities backed with sub-prime mortgage widely held by financial firms lost most of their values. This resulted in declines in capital of many banks coupled with tightening credit around the world. There were large scale insolvent threats to investment banks and other institutions. As the net worth of banks and other financial institutions deteriorated because of losses related to sub-prime mortgages, providers of insurance cover find it difficult to settle their counter parties. The development created uncertainty and loss of confidence across the system as investors could not get strong insurance company to pay or cover mortgage defaults.

According to Balonga(2009), another casual factor of the global crisis was the investment of large amount of debts or leverages in Mortgage Backed Security(MBS) in anticipation of rising house prices. The borrowing at a lower interest rate and investing the proceeds at a higher interest rate was more or less a financial leverage designed to make profit in times of housing boom. Unfortunately, it turned sour when house prices faltered leading to large losses and rapid defaults in mortgages. Thus, investors including financial institutions holding MBS suffered significant losses from mortgage payment defaults and the decline in the value of MBS.

The delay in taking actions by the US government against the imminent crisis was also adduced to the worsening state of the crisis. Aluko(2009) observed that the US government did not act in good time, not until when the large and respected investment banks started to report huge losses. The monetary authority initially believed that they are solely concerned with price and financial stability, and less concerned with avoiding asset price bubbles such as the housing phenomenon. Various stakeholders and economists viewed that the current American Regulatory framework was loose and outdated, while Securities and Exchange Commission (2009) opined that self regulation of investment banks was not properly coordinated.

However, the U.S. government and the IMF (2009) on their own part felt that they could react after such bubbles burst to minimize collateral damage to the economy rather than trying to prevent or stop the bubble itself.

The undisciplined way of using credit cards by card owners was another factor that contributed to the economic crisis (Balonga, 2009). An unsustainable personal debt overhang eventually subverts the ability of consumers to consume as larger percentages of income are spent on debt servicing and repayments. Moreover, the credit card holders use the instrument to purchase largely imported goods, which consequently affect the Balance of Payments (BOPs) in particular, increasing the amount of dollar liabilities held by non- Americans abroad.

\section{The Global Economic Meltdown And Nigerian Economy}

Although, the global financial crisis has affected both poor and rich nations, the severity of the impact on individual countries vary according to their economic, social, political and cultural settings. Sensing the panic mood in Nigeria shortly after the financial crisis erupted in the United States, and the widespread social and economic effects around the globe, the then CBN Governor, Charles Soludo, proclaimed that the Nigerian economy would not suffer serious adverse impact because of Nigeria's low integration into the global economy.

However, everyone then knew that the CBN was trying to be positive because expressing doubt on the health of the banking sector would have triggered off serious national panic. The leaders have however, started to sing a different song as they realized that the society would not escape unharmed by the global financial crisis because Nigeria is part of the global economy. 
In fact, the impact of the global financial crisis has reached the shores of Nigeria as the fear of global economic recession has started to drive down oil prices. According to Soludo (2008), oil prices had fallen down below $\$ 50$ a barrel from its peak of $\$ 147$ a barrel in July 2008. As Nigeria depends precariously on oil revenues, the political leaders had lamented that the economy was under threat because $\$ 50$ was below the $\$ 58$ oil benchmark for the 2008 budget. And pressures from the expectations that oil prices could slide further down had forced the Federal Government to reduce the 2009 budget bench mark to $\$ 45$ per barrel. And since more than 85 per cent of the monthly allocations to federal, state and local governments are derived from oil revenues, the falling oil prices could reduce the amount of monthly allocation in the years ahead.

Also, the United States, whose ailing economy triggered off the financial global crisis, is among the main importers of Nigeria's crude oil, any problem in the economies of the nations that trade with Nigeria will negatively affect Nigeria's earnings. A reduction in demand for made-in Nigeria goods and services actually destroyed the economy as the workers that produce the products would lose their jobs. This surely has skyrocketed the level of unemployment in the country. Many Nigerians in Diaspora were affected and the money they normally remitted home for development purposes were cut off. While the majority of countries with massive oil wealth have been spending their surplus earnings from the rising oil prices on domestic social programmes and building infrastructure to improve their economy after the crisis, Nigeria's democratic authoritarian government has been complaining that it has no money to repair the dilapidated infrastructure and to, meet the demand of the people. For instance, Academic Staff Union of Universities (ASUU) have gone on strike for the past two months to protest their poor working conditions and yet to be recalled.

In another dimension, our political class members have hidden under the global financial crisis to siphon off the money meant for the country. This pervasive corruption and disrespect for rule of law have led to the collapse of many small and medium scale industries in the country due to the erratic electricity supply and their inability to power their private generators because of high cost of fuel.

\section{The Effect Of The Global Financial Crisis On Nigerian Banks}

The development of the banking sector is crucial to the survival of the entire economy. Therefore, efforts must be geared towards sustaining the system. In other words, Cooperation is needed on the parts of government and private sector so as to have a sound banking financial system. The financial system of a nation is to intermediate between those who have surplus funds to lend and those who require borrowed funds. The efficient performance of fund mobilization and lending functions is lacking in most developing nations. This in most cases has been the foundation of crisis in the Nigerian banking system before the global financial crisis phenomenon.

The global financial crisis has affected the Nigerian financial system in the following ways:

(i) Weakening of the financial market - It has shaken the foundations of the financial architecture, the credit and equity markets and the framework of financial regulations, assets valuations and transfer of risks in the most developing countries. It has generally weakened the financial institutions owing to write-offs of toxic assets and corporate and consumer credit losses. This has led to the loss of confidence or trust in the just developing Nigerian financial system thereby threatening the financial stability or the country. The sudden panic in the financial market spurred investors to divest out of risky mortgage bonds and equities into commodities as store of values.

(ii) Job losses and drop in business activities - The financial crisis has led to loss of job and has lowered the rate of business activity in the country. Many of the Bank workers have been laid off since the period of the crisis up till now.

(iii) General shrinking of global financial flows and foreign investment- Overseas Development Assistance (ODA) and remittances have gone down as a result of loss of confidence in the market. The private capital flows, which in 2007 surged to $\$ 53$ billion for the first time exceeding foreign aid to the continent declined by 40per cent with that of Nigeria falling by over 60 per cent (CBN, 2008). Donor countries increased aid to Africa in 2008 but is about $\$ 20$ billion short of commitment since the global crisis. This is as a result of the mounting fiscal pressures to stimulate the donors' own economies. Remittances, which had peaked at about $\$ 20$ billion a year in 2008, declined by 4.4 per cent in 2009 .

(iv) Drop in All- Share Index- The stock market recorded unprecedented losses at the end of December 2008. The market capitalization which was 13.0trillion at the Nigerian Stock Exchange (NSE) in September 2008, fell to $\$ 9.1$ trillion in September, 2009(NSE 2009). The individual share prices in the Nigeria Capital market crumbled and are yet to make considerable improvement. This has destroyed further the confidence reposed on the Nigerian Capital Market.

(v) General global credit crunch which push up interest rates on lines of credit for Nigerian banks- The implication of this scenario is that it has made it difficult for the country to open new lines of credit and 
where applicable, with higher interest rates. This has also pushed the creditor countries to call up the lines of foreign creditors hitherto enjoyed by Nigerian banks.

(vi) Reduction in GDP Growth- Nigeria for instance, had its output down in the first quarter of 2009 to 4.85 per cent from 5.75 per cent estimated for 2008(CBN, 2009)

\section{Corruption As A Major Threat To The Nigerian Financial System}

It is very saddening to note that while the Nigerian financial system is yet to recuperate from the shock of the 2008 global financial crisis, the perpetrator and master-minder country has recovered from the financial experience. It has worsened to the level that the U.S economy after recovering from the crisis is now lending money to many African countries including Nigeria in order to get themselves healed from the shock.

Bewaji(2013) stated: "What happened in 2008 was the consequence of the weight of the fraud that was perpetrated in the years running to 2007 and 2008. Fortunately or unfortunately, for those that were involved, these were happening at the same time that we were having the global meltdown. The global meltdown was not treated like a ghost by other countries as we did in Nigeria".

As stated above, the Nigerian financial system has not been functioning well before the coming of the global economic meltdown. Unfortunately, the global phenomenon has been used as a covering shield from the inefficiency and fraudulent acts of the various players in the financial system.

In addition, it is worthy of attention that a smaller country in Africa, Uganda, did not feel the shock as Nigeria did. The Uganda's financial system is dominated by commercial banks but however, the banks had very little exposure to the type of toxic assets, which caused failed financial institutions even in the advanced economies. More so, banks in Uganda do not rely on short term foreign borrowings to mobilize funds, and they ensure high degree of surveillance on the financial condition of their commercial banks (Okonjo-Iweala, 2009). There have been reported cases of many of the Nigerian banks' managers who have swindled the banks' funds for their personal use, though sacked but the monies are yet to be returned to the coffers of such banks. This has reduced the level of liquidity of those banks. No wonder why some of the banks lend out their limited funds at exorbitant rate of interest as high as 25 percent or 26 per cent. The monetary authorities have been passive on this.

\section{Recommended Solutions}

In order to reduce, if not total eradication of failure associated with Nigerian banks and the economy as a whole, the following recommendations are given.

(i) The monetary authorities and the supervisory institutions, the central bank of Nigeria (CBN) and the Nigeria deposit insurance corporation (NDIC) should be given authority to carry out their sanitizing responsibility.

The autonomy which the CBN has been clamouring for should be given. This will enable the CBN to act without fear and favour and by this, prevent distress in banks without recourse to the federal ministry of finance for authority.

(ii) Some banks failed because of mismanagement of banking operation by inexperienced personnel. Bewaji (2013) rightly noted that the Nigeria financed market is been run by people with shallow knowledge about it. It is hereby advised that square peg should not be put in the round hole as a result of political influence. This has been affecting the sector negatively. Enabling laws governing the concerned institutions should be mastered by the stakeholder in order to drive home maximum performance and productivity.

(iii) New banks springing up in the economy should be thoroughly assessed as to their base before been granted operating licenses. This will reduce the banks' hot chase on the expatriate short term deposit which has been serving as window dressing to deceive the CBN. It is also suggested that the CBN should regularly review the minimum paid up capital with the level of inflation in mind.

(iv) Those found guilty of fraud be punished so that people will not be toiling with a sensitive sector that can easily trigger the total economy if not well handled. In fact, no perpetrator should be allowed to go free even after confiscating the property acquired with innocent depositors' funds.

(v) The government and the monetary authority should reposition the financial climate of Nigeria in order to make attractive to depositor and investors. The sector should always be ready to hedge against any unforeseen situation arising from both internal and external environments. 


\section{References}

[1]. Bewaji Wunmi (2013): Fraud, not global meltdown, led to2008 stock market crash, The Nigerian Tribune, Monday 11, Feb

[2]. Balonga Jean (2009) "The Global Financial Crises and Oil and Gas Sector of the Nigeria Economy Business Day, Jan 30-1 ${ }^{\text {st }}$ Feb

[3]. Soludo C. (2009) "Global Financial and Economic Crisis: How Vulnerable is Nigeria?

[4]. Okonjo- Iweala, N. (2009) "The Global Financial Crisis: Impact and Implications For Nigeria", Economic Confidential, Abuja, March 16.

[5]. Baker Dean (2008) "The Housing bubbles and the Financial Crisis" center for Economic and Policy Research.

[6]. Aluko M.E (2009) The Global Financial Meltdown: Impact on Nigeria's Capital market and Foreign Reserves.

[7]. IMF(2009) The implications of the Global Financial crisis for Low- income countries, Washington DC.

[8]. SEC (2009) "Sec blames banks, others for capital market crisis" The Guardian, Feb 3.

[9]. Nwankwo G.O (1980) Money and capital markets in Nigeria Today, University of Lagos Press.

[10]. CBN (2008). CBN statistical bulletin, golden jubilee edition

[11]. CBN (2009). CBN annual report

[12]. NSE (2009). The Nigeria stock exchange fact book. 